\title{
A PSYCHOLOGICAL 'HINGE' IN NATIONAL DEFENCE
}

JUST as German strategy concentrated on a weak hinge in the military defences of France, so in its general technique of invasion the German Command thrusts at what may be called a psychological hinge in the national defences : the weak point where military discipline ends and civil organization begins. Invasion by parachute troops co-operating with secret agents is the most dramatic form of the attack on this weak hinge. Its success in the neutral countries depended on military operations being carried out in an area which was still organized for civil life and looking to civil authority for direction. Military attack at that point in the national structure caused panic and confusion.

In Great Britain we hope that forewarned is forearmed. The question is, against what exactly have we been forewarned? Against parachute invaders aided by secret agents? But quite different tactics might be employed and yet fulfil the same military purpose through having the same fundamental effect psychologically.

This effect can perhaps be best described as a form of bewilderment. It results from the sudden shattering of deep-seated assumptions and expectations which the civilian-and possibly the soldier too-harbours about warfare. These assumptions are partly expressed in the formulated laws and usages of war. But the most important, psychologically, spring from less definite factors, such as custom, long-sanctioned sentiment, tradition ; or, in more modish guise, from the prevailing 'cultural patterns'. The German policy is to disrupt those patterns, and to take advantage of the resulting bewilderment.

One of our clearest cultural patterns-so long established as to seem 'natural'-is that of a strict differentiation of the military function within the community, with a specialized sub-group to perform it. Without this pattern there would be no foundation for the laws governing the treatment of non-combatants in warfare. This pattern has persisted up to the present time. Bombing from the air, it is true, brings civilians within range of military dangers and does something to blur the distinction between soldiers and others. Yet in its psychological effects the bombing we have experienced in Britain has been in some ways more like a natural calamity. It has been an ordeal in which the civilian has remained comparatively inert, passively enduring.

The psychological effect seems to be very different when the enemy's parachute troops are actually among civilians, carrying out a military attack against communications and transport in areas where ordinary civil life is the rule. If, in addition, low-flying aircraft deliberately machinegun civilians in order to cause confusion, the sense of a personal attack is enhanced. Such attacks represent a much more intimate infiltration of military purposes into civilian life than aerial bombing has done in the past. The enemy is using his attack on civilians for a direct and immediate military purpose, that of hampering the army's operations by means of civil confusion.

Yet the civilians remain civilians. They have no training, no equipment, and no organization for resisting, and--what may be worse-they have no clear right even to resist by armed force.

The blurring of established social patterns is carried further in the use made by Germany of secret agents. The so-called 'Fifth Column' in the invaded countries has engaged not merely in espionage and sabotage, but also in actual military co-operation with enemy troops. Against these agents, presumably, even civilians would be entitled to use any force that they could. This seems to be implied in the official leaflet "If the Invader Comes", when it instructs factories to organize their own system of defence against sudden attack :

"If you are in charge of a factory, store or other works, organise its defence at once. If you are a worker, make sure that you understand the system of defence that has been organised and know what part you have to play in it. Remember always that parachutists and fifth column men are powerless against any organised resistance. They can only succeed if they can create disorganisation. Make certain that no suspicious strangers enter your premises."

Examined carefully, the official wording here (and throughout the leaflet) can be seen to avoid giving sanction to armed action by civilians against parachute troops. The caution and vagueness of official pronouncement reflect the central difficulty : that of securing safety while still adhering to the usage of war in totally novel circumstances. 
The Local Defence Volunteers represent the main attempt in Great Britain to meet this difficulty. They form the answer to a ruse which takes advantage of laws and customs that grew up in totally different circumstances from those created by the German strategem. The ban on the franc-tireur was based on the experience of armies of occupation which were in full military control of enemy territory. What were not envisaged were acts of brigandage by small bands of troops within territory the ordinary military defences of which are still intact. The enlistment of Local Defence Volunteers succeeds in maintaining the clear difference in military law between the soldier and the civilian, but it leavens the civilian population with men equipped for military functions and entitled to exercise military rights.

The fundamental answer to the German policy, however, has not yet been discovered. Full defence against the policy of social confusion can consist in nothing less than restoring psychological clarity to the situation. The secret agent was effective in countries where his own clear-cut intentions contrasted with the divided sympathies and faltering policy of those around him. In the Netherlands, it is reported, the 'Fifth Column' organizations were perfectly well known but were not proceeded against for fear of provoking Germany. In Britain, on the other hand, clarity of national intention should now be more easily achievable. Given that, police action, with the co-operation of the public, can handle the danger of the secret agent.

Against parachute invaders the precautions must in the main be military. Yet here the importance of the psychological 'hinge' can too easily be under-estimated and neglected. A civilian population untempered by military training and yet exposed to military attack presents a problem which has not yet been fully solved. The German politico-military Command has deliberately disrupted the older social patterns. Diplomatic pressure, military assault, brigandage, espionage, treachery, revolution, these are all familiar. But in the past they have been clearly distinguishable from each other. Now, however, the separate patterns have been dissolved and the new situation is a bewildering social hybrid. It remains bewildering so long as we try to grasp it in terms of the older patterns. In particular, the complete gulf between the civilians and the armed forces is an anachronism.

Up to the present, the policy of the army has been to work in the greatest possible isolation from civilian life. The civilian has been encouraged to cultivate total ignorance of the meaning of any military activity that cannot be entirely concealed from him. It should scarcely need technical psychology to make it clear that this policy will not prevent gossiping, rumour-mongering, and the spread of all manner of alarms and forebodings. Again, the policy towards civilians in a battle area has been the negative one of either evacuating them or of keeping them immobile and inert. But when battle areas are no longer neatly delimited, and new tactics make civilian panic much more likely, this policy is not certain of success. Moreover, it ignores the fact that the army may require much more positive co-operation from civilians.

The new circumstances make it dangerous for the army to persist in regarding civilians as nothing but an 'unavoidable nuisance. It would seem that the weak hinge between civil life and military organization must be strengthened. Much could certainly be done by the military authorities, without any leakage of vital information, to give the impression of taking the public into their confidence far more than they do at present. The leaflet "If the Invader Comes" makes it clear that the co-operation of the civilian public may be needed by the army authorities. Any more detailed expansion of the bare hints dropped by that leaflet would do something towards strengthening the weak hinge.

Many methods could undoubtedly be found of implementing such a policy if it were accepted in principle. There would be value even in so obvious a device as lectures to civilian audiences dealing in a general and non-committal way with the strategy and tactics which we may at any moment find ourselves involved in. Broadcasts have done a very little in this direction. In some ways, lectures given by military men in the actual presence of small civilian audiences would be more useful. They could have more local relevance. They would give more visible reality to the contact between eivilians and military authorities.

The fact is that at present, to a great proportion of the civil population, a military officer on duty is psychologically foreign. This was of little account when wars were fought on a front line. In the new circumstances of war it is more serious. It represents a danger which can probably be met only by giving the civilian population a more visible, more local, and more definite role in their support of those who carry out the specialized military function. 